\title{
Teaching Reform and Exploration of Architectural Design Course Under the Trainings of Innovative Talents
}

\author{
Yu Qin ${ }^{1 *}$, Tingting Wang ${ }^{1}$ \\ ${ }^{1}$ School of Construction Engineering, Kunming University, Kunming, Yunnan 650214, China \\ *Corresponding author. Email: 593988872@qq.com
}

\begin{abstract}
With the rapid development of social economy, talent demand is constantly updated. Under the new situation, the cultivation of innovative talents has become an important subject in the transformation and development of college education. This paper objectively analyzes the teaching maladies that have existed in architectural design course for many years, based on the first-line teaching practice. From the point of view of scientific innovation, the teaching plan is re-examined, and the relevant reform ideas are put forward on the five levels of educational idea, teaching content, teaching method, teaching place and teaching evaluation respectively, in order to provide experience and reference for the sustainable development of architectural design curriculum in local colleges and universities.
\end{abstract}

Keywords: cultivation of innovative talent, architectural design, teaching reform

\section{INTRODUCTION}

In today's comprehensive social and economic development of China, the demand for talent is constantly rising. Talent training can not be separated from education. In 2017, The 13th Five-Year Plan for Education Development proposed to promote education and teaching reform [1]. And then General Secretary Xi Jinping clearly pointed out that "Development is the first priority, talent is the first resource, and innovation is the first motive force" [2]. It is based on such policy guidance that colleges and universities have set up the goal and direction of cultivating innovative talents, and aim to promote the construction of innovative talents training through a series of teaching reforms.

The cultivation of talents is finally implemented in the curriculum, reflected in the classroom [3]. As an old specialty with a certain historical age, how to actively implement the development requirements of reform and innovation, architecture needs serious thinking and self-examination. Architecture design course which is architecture major's core course, has always had the characteristics of high credit and high school hours, occupies an important part of professional teaching, its transformation will play a decisive role in professional innovation and development. Therefore, combined with many years of first-line teaching practice, we take the architectural design course as the main research object, correctly understand the training goal, and deeply reflect on the problems and shortcomings, in-depth analyze the content of the course, seriously study the teaching methods, and try to carry out multidimensional rectification and promotion of the architectural design course.

\section{TRADITIONAL TEACHING MODE OF ARCHITECTURAL DESIGN COURSE AND ITS DISADVANTAGES}

The contemporary architecture education in China is deeply influenced by the western modernist architecture thoughts, especially the Bauhaus school in Germany, can be said to be the cradle of modern architecture. From the early "old eight schools" to more and more new undergraduate colleges, the teaching thought and system of architecture major also inherited the Bauhaus gene, and continued the rational teaching method which emphasized space, function and technology.

The influence and contribution of Bauhaus to modern architectural design is beyond doubt. It not only creates scientific design techniques, puts forward the combination of art and technology, but also changes the focus of design from empty appearance to profound connotation. However, with the change of times, the education and teaching of architectural design should take full advantage of historical nutrition, combine the regional environment and social needs, think deeply about the problems in practical teaching and the inertia of the established form, eliminate the disadvantages and seek development.

For a long time, the teaching of architectural design curriculum has followed the traditional talent training model, the teaching idea is backward, the teaching method is old, the teaching content is outdated, the teaching relation is passive, the classroom progress is inefficient, the work flow is procrastination, the appraisal method is single, and so on, have greatly restricted the development of specialty and the innovation of talents, so the teaching reform is imminent. 


\section{THE TEACHING REFORM THOUGHT OF ARCHITECTURAL DESIGN COURSE}

\subsection{Educational Philosophy}

All along, most of the architectural design courses continue the teaching methods of teachers leads apprentices, and teachers teach methods and experiences, emphasizing the dominant position of teachers, teachers are the standard, students can only imitate and listen to, manifested as a vertical one-way teaching characteristics. It is difficult for students to gain positive self-confidence and equal participation in such teaching ideas and atmosphere, so they are used to obedience and lack of thinking over time. At the same time, over the years, architectural design courses in the process of batch and stylized teaching like industrial production to students simple production and replication, teaching skills universally, rarely according to the individual characteristics of students to carry out personalized training. In addition, most of the courses focus on the training of professional skills, with little guidance on social responsibility, professionalism and humanistic literacy, which leads to the cultivation of so-called talents are extensive technicians with insufficient professional cognition and internal accomplishment, it is also a common defect in education and teaching since the reform and opening up.

It is precisely based on the misunderstanding of some educational concepts that the architectural design curriculum under the guidance of innovative talents training ideas needs to start with the renewal of educational concepts. First of all, we should change the vertical teaching mode of indoctrination to create an equal and interactive teaching atmosphere, understand and respect students' ideas and ideas, encourage good ideas and perspectives, take more guidance and inspiration, pay attention to cultivate and protect students' self-confidence, mobilize their interest points, so that the students can be really active. Second, teachers should change their usual style of authority, encourage students to think hard, ask more questions, and dare to query, cultivate critical thinking [3] and guide the healthy development of exploratory teaching and learning. Through the above two aspects, an open, democratic, equal, interactive teaching environment can be promoted to form. Third, architectural design is not only a simple technology, but also a reflection of feelings and culture. Some meaningful social research can be arranged according to the subject in the course teaching, so that students can go out of school to experience the real background and cultural knowledge outside the drawings, broaden the accumulation of knowledge and improve cultural accomplishment. And the cognition of the architect's professional ethics can be appropriately increased through the links of theoretical teaching and communication, so as to clarify the professional orientation and social responsibility [4], exercise the ability to cooperate with others, strengthen their own quality cultivation, and cultivate "responsible, cooperative, cultural, sentimental" innovative talents.

\subsection{Teaching Content}

Architectural design courses, as the core backbone of architecture major, with high credit and hours, usually run through the professional learning process of 4-5 years in school in the way of series courses. However, in the traditional teaching practice, there is a lack of necessary teaching communication among the teaching groups in the architectural design course, and the vertical correlation degree of the teaching content is insufficient. Meanwhile, horizontally, the teaching targets and subject content of each grade architectural design course are not clear enough, either following the old design task, no changed for years, or changing the teaching content at will, without systematicness. Moreover, from the current consistent teaching procedure, the architectural design curriculum follows the old pattern of "Assignment of tasks- First sketch design- Second sketch design- Formal drawing" decades ago. Teaching has not been integrated into the current social development research and thinking, nor has it actively guided the innovation of design concepts, more rarely to the depth of technical issues.

In view of this situation, on the one hand, teaching reform emphasizes the principle of "vertical coherence, horizontal focus" on the whole. That is, vertically the architectural design course is a series of courses, which requires the complete teaching system, clear context, consistent and orderly teaching content. Horizontally, it is required to carefully analyze the teaching tasks of each stage with the term as the unit, to clarify the teaching objectives, and to formulate scientific and reasonable teaching contents and programs closely around the requirements of the objectives. On the other hand, in the course of teaching reform, we make the teaching links of designing courses more concrete every semester, and put forward five teaching steps, (as shown in Figure 1) that are: Step 1, Assigning tasks and teaching knowledge. Based on the characteristics of the teaching stage and the requirements of the curriculum to formulate appropriate design tasks, the middle and senior grade can choose the actual project or the competition topic in the same time section as the teaching content, strives to be close to the social reality. Step 2, Field survey and reporting communication. This step is an essential part of matching real questions. Students can collect data in groups through on-site research and exchange discussions. This process can fully arouse students' enthusiasm for work, helps to better understand and grasp the design conditions. Step 3: Conceptual presentation and sketch Design. Design focuses on creativity, good design works come from good creative ideas. In view of the lack of concept training and innovation consciousness in the past teaching, the concept design link is specially added in the sketch design stage [5]. The design idea is established first, and then the sketch scheme is deepened. Step 4, Technical learning and deepening design. In the past, the teaching of design course only stayed in the simple design and expression of the scheme, without further guidance and study on the technical level, it makes professional teaching and employment market has always a large gap, can not be 
well connected. So, the course of architectural design after the reform has added the deepening teaching of structure selection, construction practices, technical specifications, green building analysis and other aspects on the basis of the scheme design, so that students can have a deeper understanding of the program implementation, and the teaching content is more realistic and feasible. Step 5, Completion the works and reviewing the presentation. After the previous several steps of grinding, design work will be greatly improved both in the concept and depth, the final form will also break through the previous single drawing form, can be supplemented by models, construction, animation, VR and other ways to improve the sense of vision and experience. At the exhibition stage, students elaborate on their own works first, and then teachers and experts comment. Teachers and students can discuss and communicate with each other, at the same time students can observe and learn from each other too. This link is a summary and reflection of the previous work, from which to find problems, find gaps, consolidate knowledge, and increase interest.[6]

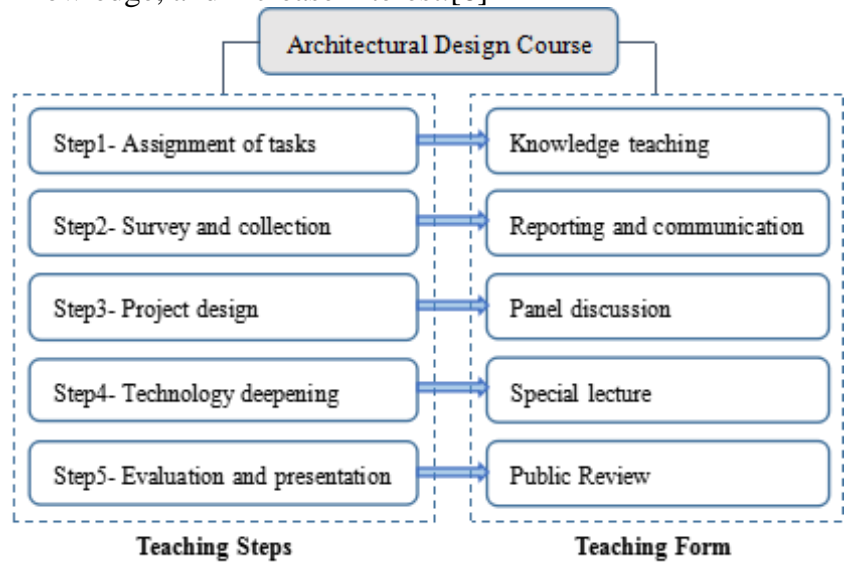

Figure 1 Five-step Teaching Illustration

\subsection{Teaching Methods}

On the basis of the innovation of teaching contents, the teaching methods also need to be changed accordingly, mainly reflected in the following three aspects:

Table 1 Teaching Method Innovation Table

\begin{tabular}{|l|l|l|}
\hline $\begin{array}{l}\text { Teaching } \\
\text { Methods }\end{array}$ & $\begin{array}{l}\text { Traditional } \\
\text { Teaching }\end{array}$ & $\begin{array}{l}\text { Innovative } \\
\text { Teaching }\end{array}$ \\
\hline Subject & teacher & student \\
\hline Relations & one-way & two-way \\
\hline Form & independent & cooperative \\
\hline Approach & single & multiple \\
\hline
\end{tabular}

\subsubsection{Subject From Teacher To Student}

For a long time, teachers have been the subject of teaching activities, responsible for teaching knowledge and skills, students are used to receiving guidance and passive learning.
In such a mode, students are always in a state of passive acceptance, and do not really participate in the activities of teaching and learning, naturally it is easy to lack learning enthusiasm and initiative. In the architectural design course, teachers should change their roles, walk down from the lecture position to organize teaching activities as host. In classroom teaching, students should be the real protagonists, not recipients and bystanders, but leaders and participants, to turn the knowledge acquisition from simple "indoctrination" to active "exploration", reverse the fixed learning methods and explore the establishment of new teaching models.

\subsubsection{Relations From One-Way To Two-Way}

In traditional teaching, the course of architectural design inculcates knowledge and skills in students through teachers. In this teaching process, it embodies the vertical one-way teaching relationship from top to bottom [7]. Teachers own absolute right of speech based on their own knowledge and experience, students can only obey, accept and continue them. However, with the development of the times, this blindly follow from beginning to end has been contrary to the development needs. Therefore, it is necessary to put forward corresponding adjustment suggestions for this backward teaching relationship, guide classroom teaching to be carry out in an orderly manner in the situation of equality and interaction between teachers and students. Teachers should stop flaunting "experience" and "convention", but encourage students to think boldly, ask questions bravely, explore actively, acquire knowledge and seek innovation in the process of mutual communication and exchange.

\subsubsection{Form From Independence To Cooperation}

In the past, the architectural design courses which all undertaken by the architecture teachers who emphasized on programmes over technology in teaching generally, that leaded to the vacancy and bias of students' cognition, affected the in-depth development of design and collaboration with other professions. In addition, the design homework is often done independently by the individual students, fighting alone working hard, and the final effect is not ideal. Therefore, in the teaching reform, it is suggested that teachers from different professional backgrounds should be organized to participate in the teaching guidance according to the different task types, characteristics and difficulty, the form of operation can also consider the multi-person cooperation way, so as to make it closer to the operation of the actual project. In this process, students can not only acquire more comprehensive knowledge structure, improve communication and cooperation ability, but also improve the overall quality and depth of homework. 


\subsubsection{Approach From Single To Multiple}

Classroom teaching is a well-known teaching approach, it has long played an important role in the process of teaching and learning. This classroom on-site teaching has many advantages, but also has many limitations. The most important thing is that all people need to participate in teaching activities at the same time and place, and at the end of the course, the teaching is basically terminated. With the popularization of modern network technology, teaching has given a lot of space and flexible processing. The architectural design curriculum encourages the development from the traditional single field teaching to the online\&offline integrated teaching mode. Teachers can use network resources to expand teaching, online communication and guidance, to construct of cloud-based teaching resources, and to realize the teaching guidance of any time and space. This method greatly breaks through the limitation of traditional teaching, facilitates the use of teachers and students, and can also avoid the impact of unexpected events on teaching activities. For example, in the current state of the nation's response to COVID-19 which caused the suspension of schools, it has showed great advantages that makes teachings to continue.

\subsection{Teaching Place}

On the basis of positive changes in teaching contents and teaching methods, the teaching places of architectural design courses can also be innovated accordingly, changing the closed and solidified classroom space and independent self-teaching mode in the past, to organize teaching activities with an open, flexible, inclusive and multiple posture [7]. In the five steps of teaching content reform, the corresponding social research, group discussion, special lectures, open communication, open evaluation and exhibition are interspersed respectively, teaching sites can be extended from campus to the outside, from single spot to multiple spot, transforming fixed rigid lectures into flexible and diverse activities. On the one hand, changing the form of determinant arrangement in traditional classrooms to group or enclosed spaces that facilitate discussion and communication, leading to an equal and interactive teaching atmosphere. On the other hand, breaking down discipline barriers, the corresponding technical teachers can be introduced in different stages to participate in teaching combined the needs of curriculum design, so as to realize the cooperation and integration between different professional subjects. Third, through the method of "taking students out and bringing resources in", the connection between school and society is strengthened, and the gap between talent training and social demand is weakened.

\subsection{Teaching Evaluation}

The quality requirement of the final result has always been emphasized in the teaching evaluation of architectural design course. Because the design work is often expressed by the drawings, the final effect often becomes the main basis for evaluating the merits and demerits of the design works, which leads to the students' misunderstanding of "pay more attention to the result than the process" and "pay more attention to the effect than the content " in the architectural design course.

Therefore, one of the main aspects of teaching reform of architectural design curriculum is to reset the evaluation basis, to adjust the evaluation criteria , and transform the final evaluation into process evaluation [8]. Through scientific evaluation methods to fully mobilize the enthusiasm of students, encourage them to innovate. By establishing the detailed evaluation in the learning process, it truly reflects the students' learning attitude, progress, weaknesses, personality advantages and so on, then promotes the best teaching effect with good and effective teaching interaction.

Teaching is a continuous, procedural communication. It is not scientific to rate any single or single score as final, the course should be evaluated by the multiple steps evaluation results multiplied by the corresponding weight ratio. In combination with the five-step reform of teaching content of the architectural design curriculum, the teaching evaluation also needs to be divided into parts, interspersed with them, forming a number of evaluation processes. This multi-angle and diversified evaluation method can help to pay attention to each student's learning situation, find problems in the first time and guide the improvement in time. It can also help to play the incentive role of evaluation method and promote the active development of students' daily learning. Moreover, it can help to feedback the real teaching situation, teachers can see the teaching effect through each process evaluation and make timely analysis and adjustment. The scientific evaluation basis and evaluation method will change the lazy and inefficient teaching situation of the traditional architectural design course, promote the teaching process to reverse in the direction of initiative, reality and efficiency.

\section{SUMMARY}

The five level reform measures summarized in this paper are the positive exploration of our local colleges and universities to deal with the new situation and new changes in recent years, and also the scientific change of self-examination and seeking development of architecture major, which has got better feedback to a certain extent and achieved good results. But because of the comprehensiveness and complexity of architectural design curriculum, teaching reform is difficult to put in place in one step. This requires constant thinking and deepening in the teaching process, making scientific and detailed teaching plans for different grades, and implementing the goal of cultivating innovative talents in every course and every teaching. In a word, only by keeping the consciousness of innovation, updating the teaching content in time, strengthening the two-way 
interaction between teaching and learning, and establishing scientific and effective evaluation methods, can we promote the sustainable development of architectural design curriculum in teaching.

\section{ACKNOWLEDGMENT}

This work was supported by the Education and Teaching Reform Project of Kunming University in 2018 Research on Teaching Reform and Evaluation System of Architectural Design Courses under the Train of Innovative Talents.

\section{REFERENCES}

[1] http://www.gov.cn/zhengce/content/2017-01/19/conte nt_5161341.htm

[2] http://www.xinhuanet.com/politics/2018-03/07/c_112 2502719.htm

[3] Wei Ya, Liu xuedong,Yang Zhihe, Exploration and Reform Thinking _ the Law of Cultivating Innovative Talents in Colleges and Universities, Journal of Suzhou Education Institute, 22(06)(2019)56-58. DOI: https://doi.org/10.13985/j.cnki.34-1227/c.2019.06.018

[4] Li Xueqin, Lu Shengpeng, A Study on Teaching
Reform of Architectural Design Course Based on Innovative Idea, Theory and Practice of Contemporary Education, 03(02)(2011)77-79.

[5] Li Xiaodan, Research, Diversification and Systematization:Exploration and Research about Reform Practice of Teaching in Architecture Design of Grade 3, Huazhong Architecture, 28(06)(2010)175-177. DOI : https://doi.org/10.13942/j.cnki.hzjz.2010.06.048

[6] Cui Yi, Teaching Method on Training Rational Thinking Process: Experimental Practice of Achitectural Design in the Second Grade, Huazhong Architecture, 29(10)(2011)171-174. DOI : 10.13942/j.cnki.hzjz.2011.10.045

[7] Zhang Yi, Wang Ning, University Teaching Spatial Morphology Based on the Innovative Personnel Training, Huazhong Architecture, 37(10)(2019)75-78. DOI: https://doi.org/10.13942/j.cnki.hzjz.2019.10.016

[8] Li Pei-zhen, Zhang Bo, Shan Jia-zeng, Zhang Wei-ping, Study on Examination and Evaluation of Course Based on OBE Theory, Education Teaching Forum,13(2019)83-85. 